\title{
Poly (vinyl alcohol) hydrogel membrane as electrolyte for direct borohydride fuel cells
}

\author{
N A CHOUDHURY ${ }^{\mathrm{a}}$, S K PRASHANT ${ }^{\mathrm{b}}, \mathrm{S}^{\mathrm{PITCHUMANI}}{ }^{\mathrm{b}}, \mathrm{P}^{\mathrm{SRIDHAR}}{ }^{\mathrm{b}}$ and \\ A K SHUKLA ${ }^{\mathrm{a}, \mathrm{b}, *}$ \\ ${ }^{a}$ Solid State and Structural Chemistry Unit, Indian Institute of Science, Bangalore 560012 \\ ${ }^{\mathrm{b}}$ Central Electrochemical Research Institute, Karaikudi 630006 \\ e-mail: shukla@sscu.iisc.ernet.in
}

\begin{abstract}
A direct borohydride fuel cell (DBFC) employing a poly (vinyl alcohol) hydrogel membrane electrolyte (PHME) is reported. The DBFC employs an $\mathrm{AB}_{5}$ Misch metal alloy as anode and a goldplated stainless steel mesh as cathode in conjunction with aqueous alkaline solution of sodium borohydride as fuel and aqueous acidified solution of hydrogen peroxide as oxidant. Room temperature performances of the PHME-based DBFC in respect of peak power outputs; ex-situ cross-over of oxidant, fuel, anolyte and catholyte across the membrane electrolytes; utilization efficiencies of fuel and oxidant, as also cell performance durability are compared with a similar DBFC employing a Nafion ${ }^{\circledR}-117$ membrane electrolyte (NME). Peak power densities of $\sim 30$ and $\sim 40 \mathrm{~mW} \mathrm{~cm}{ }^{-2}$ are observed for the DBFCs with PHME and NME, respectively. The crossover of $\mathrm{NaBH}_{4}$ across both the membranes has been found to be very low. The utilization efficiencies of $\mathrm{NaBH}_{4}$ and $\mathrm{H}_{2} \mathrm{O}_{2}$ are found to be $\sim 24$ and $\sim 59 \%$, respectively for the PHME-based DBFC; $\sim 18$ and $\sim 62 \%$, respectively for the NME-based DBFC. The PHME and NME-based DBFCs exhibit operational cell potentials of $\sim 1.2$ and $\sim 1.4 \mathrm{~V}$, respectively at a load current density of $10 \mathrm{~mA} \mathrm{~cm}^{-2}$ for $\sim 100 \mathrm{~h}$.
\end{abstract}

Keywords. Poly (vinyl alcohol) hydrogel; Nafion ${ }^{\circledR}-117$ membrane; cross over; utilization efficiency; direct borohydride fuel cell; sodium borohydride; hydrogen peroxide.

\section{Introduction}

Fuel cells are electrochemical devices that continuously convert chemical energy into electrical energy for as long as fuel and oxidant are supplied to it. Fuel cells bear similarities to combustion engines that generate energy continuously consuming a fuel of some sort. Fuel cells are environment-friendly and hence attractive energy sources for future generation. Among the various types of fuel cells, polymer electrolyte fuel cells (PEFCs) are especially promising due to their quick start-up capabilities under ambient conditions. But PEFCs suffer from carbon monoxide poisoning of platinum anode $\mathrm{e}^{1-3}$ while using reformer, and hazard related to hydrogen storage in directly-fueled PEFCs. Therefore, alternative hydrogenous liquids, such as methanol, have found application for fueling PEFCs directly. ${ }^{4-6}$ Use of methanol directly as a fuel in a PEFC simplifies the engineering issues, thereby driving down

${ }^{\dagger}$ Dedicated to the memory of the late Professor S K Rangarajan *For correspondence system complexity and hence cost. ${ }^{7}$ PEFCs employing pure or aqueous methanol as fuel, referred to as DMFCs, however remain limited by low opencircuit-potential, low electrochemical-activity in addition to methanol crossover. ${ }^{4,8}$

The problems related to low open-circuit-potential and low electrochemical-activity of DMFCs could be overcome by using various borohydrides as fuel. ${ }^{9-16}$ Sodium borohydride $\left(\mathrm{NaBH}_{4}\right)$ has the minimal heat of hydrolysis $\left(-80 \mathrm{~kJ} \mathrm{~mol}^{-1} \mathrm{H}_{2}\right)$ among all borohydrides. ${ }^{17}$ It has a capacity value of $5.67 \mathrm{Ah} \mathrm{g}^{-1}$ and a hydrogen content of $\sim 11 \mathrm{wt} \%{ }^{18}$ In the literature, Amendola et $a l^{12,13}$ are the first to report an anion exchange membrane-based DBFC. However, the borohydride-air fuel cell due to Amendola et $a l^{12,13}$ suffers from borohydride crossover as $\mathrm{BH}_{4}^{-}$-ions can easily pass through the anion exchange membrane. Moreover, it would be mandatory to scrub $\mathrm{CO}_{2}$ from the air inlet of such a fuel cell to avoid carbonate fouling. In order to mitigate borohydride-crossover, $\mathrm{Li}$ et $a l^{15,16}$ developed a DBFC employing Nafion ${ }^{\circledR}-117$ membrane as electrolyte-cum-separator and transition metal-based 
alloy as anode. Transition metal-based alloys employed as anode catalysts for electro-oxidation of $\mathrm{NaBH}_{4}$ in DBFCs is much cheaper than the platinum-based precious metal alloy catalysts employed for electro-oxidation of methanol in DMFCs. ${ }^{8,15}$ In addition, the operational temperature of DBFCs is lower than that for DMFCs. ${ }^{19}$ DBFCs employing Nafion ${ }^{\circledR}-117$ membrane electrolyte ${ }^{15,16,20,21}$ suffer from alkali crossover from anode to cathode. Use of Nafion ${ }^{\circledR}$-961 membrane electrolyte as separator reduces the cross-over of alkali enhancing utilization of oxidant at the cathode. ${ }^{22,23}$ Ironically, Nafion ${ }^{\circledR}$ membrane is expensive and therefore in order to increase the prospect of commercialization of DBFCs, it would be imperative to substitute Nafion ${ }^{\circledR}$ membranes with alternative cost-effective membranes. To this end, PVA hydrogel membranes could be attractive.

Poly (vinyl alcohol) (PVA), discovered by Haehnel and Herrmann in 1924, is one of the most widely investigated polymers in the literature. ${ }^{24-29}$ It is cheap, non-toxic and chemically stable. ${ }^{30}$ Under acidic conditions, the $-\mathrm{OH}$ groups of PVA react with - CHO groups of certain aldehydes to form acetal or hemiacetal linkages. ${ }^{31,32}$ The resultant polymeric entity with acetal or hemiacetal linkages is water insoluble and gel-like in nature. It can be cast to form thin large surface-area membranes suitable to be used as electrolyte-cum-separator in fuel cells.

In the light of the foregoing, in this communication, we report a DBFC with PVA hydro-gel membrane as electrolyte, alkaline $\mathrm{NaBH}_{4}$ as fuel and acidified $\mathrm{H}_{2} \mathrm{O}_{2}$ as oxidant. The performance of the PHME-based DBFC with regard to peak power density, reactant utilization efficiency and cell performance durability is compared with a DBFC employing NME.

\section{Experimental}

\subsection{Preparation of PVA hydrogel membrane electrolyte}

PHMEs were prepared by a solution casting method $^{31,32}$ in which a mixture of an aqueous solution of PVA (M.W. $\approx 1,25,000$; S D Fine-Chem Ltd., India) and an optimized quantity of glutaraldehyde (25\% aq. solution, Merck Specialties Pvt. Ltd., India) was cast on a glass Petri dish and left at ambient conditions of temperature and pressure for $\sim 48 \mathrm{~h}$ to allow water to evaporate. After the afore- said period, the membrane was peeled off and immersed in $1 \mathrm{M}$ sulphuric acid $(\sim 98 \% \quad \mathrm{GR}$; $d=1.84 \mathrm{~kg} \mathrm{~L}^{-1}$, Merck Ltd., India) for $1 \mathrm{~h}$ to cause the cross-linking reaction between PVA and glutaraldehyde. In a typical preparation, $80 \mathrm{~mL}$ of $0.1 \mathrm{~g} \mathrm{~mL}^{-1}$ aqueous solution of PVA was mixed with $1.6 \mathrm{~mL}$ of $25 \%$ aqueous glutaraldehyde by stirring magnetically for $4 \mathrm{~h}$ and cast on a glass Petri dish of $16 \times 20 \mathrm{~cm}^{2}$ area. The dried membrane was then peeled off and dipped in $1 \mathrm{M} \mathrm{H}_{2} \mathrm{SO}_{4}$ for gel formation.

\subsection{Preparation of $A B_{5}$ alloy}

$\mathrm{AB}_{5}$ alloy of composition $\mathrm{M}_{m} \mathrm{Ni}_{3.55} \mathrm{Al}_{0.3} \mathrm{Mn}_{0.4} \mathrm{Co}_{0.75}$, where $M_{m}$ (Misch-metal) comprises La-30 wt.\%, Ce-50 wt. \%, Nd-15 wt.\%, Pr-5 wt.\%, was employed as anode catalyst. It was prepared by arc melting stoichiometric amounts of the constituent metals in a water-cooled copper crucible under argon atmosphere. ${ }^{33-38}$ The alloy ingots were mechanically pulverized to fine powders before use in DBFCs.

\subsection{Electrochemical characterization of borohydride fuel cells}

For the electrochemical characterization of DBFCs, membrane electrode assemblies (MEAs) were prepared by sandwiching the PHME or pre-treated NME between anode and cathode. To prepare anode catalyst layer, a slurry of $\mathrm{AB}_{5}$ alloy obtained by ultra-sonicating the required amount of the alloy with $5 \mathrm{wt} . \%$ Vulcan XC-72R carbon and $7 \mathrm{wt} \%$ of Nafion ${ }^{\circledR}$ solution in 2-propanol was pasted on a gold-plated stainless steel (SS)-316 gauge of 120 mesh. The loading of alloy catalyst was $30 \mathrm{mg} \mathrm{cm}^{-2}$ and was kept identical for all the MEAs. The cathode was obtained by electroplating a gold layer of $1 \mu \mathrm{m}$ thickness onto a SS-316 gauge of 120 mesh. For preparing NME-based MEA, a layer of Nafion ${ }^{\circledR}$ in 2-propanol with a loading of $0.25 \mathrm{mg} \mathrm{cm}^{-2}$ was applied to the surface of each electrode. The MEA was obtained by hot pressing the cathode and anode on either side of a pre-treated NME under a load of $60 \mathrm{~kg} \mathrm{~cm}^{-2}$ at $125^{\circ} \mathrm{C}$ for $3 \mathrm{~min}$. While preparing PHME-based MEA, a novel method was adopted, wherein a thin layer of $0.1 \mathrm{~g} \mathrm{~mL}^{-1}$ aqueous solution of PVA was mixed with optimized quantity of aqueous glutaraldehyde solution and was pasted onto the surface of each electrode to act as binder between the PHME and the electrodes. The MEA was 


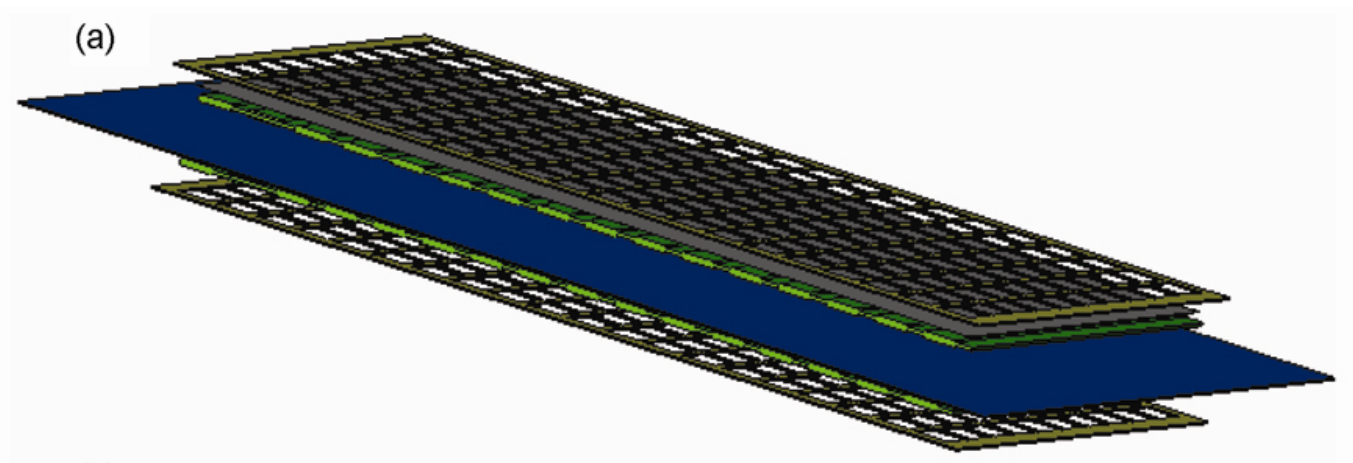

(b)

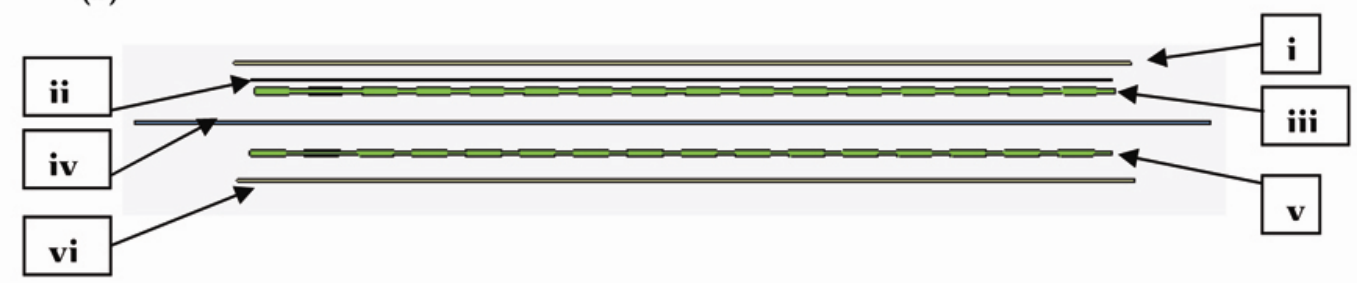

Figure 1. (a) Three-dimensional side-view of the MEA employing PHME; (b) twodimensional side-view of the PHME-based MEA: (i) gold-plated SS mesh on anode side, (ii) anode catalyst layer, (iii) PVA + glutaraldehyde binder layer on anode side, (iv) PHME, (v) PVA + glutaraldehyde binder layer on cathode side, (vi) gold-plated SS mesh used as cathode.

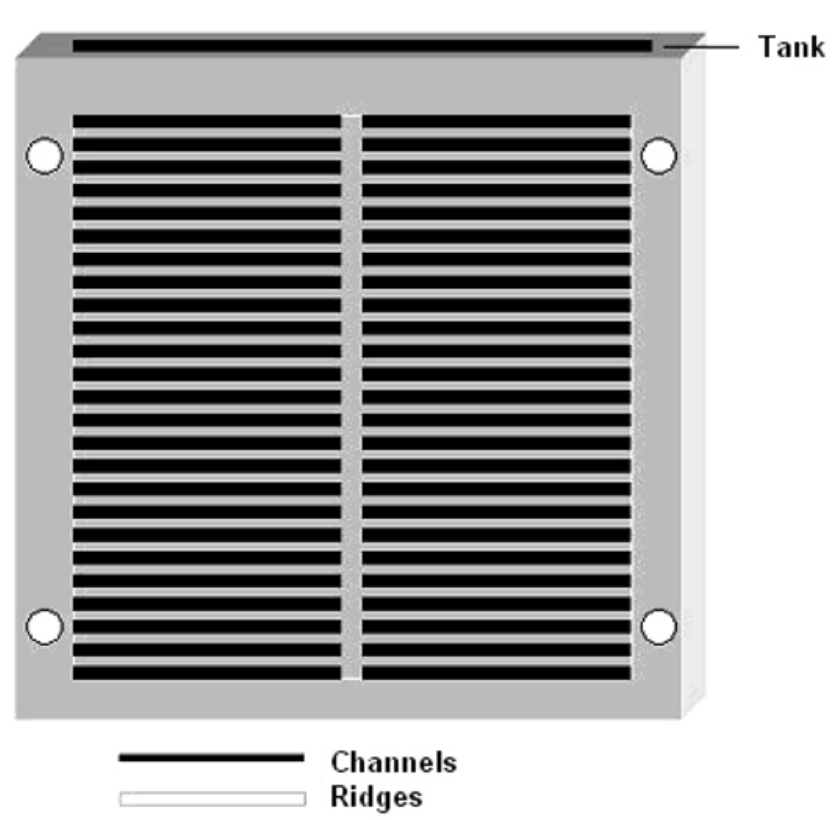

Figure 2. A schematic diagram of a typical fluid flow field plate machined from high-density graphite blocks with an active area of $9 \mathrm{~cm}^{2}$ that acted as storage tanks for fuel or oxidant.

obtained by hand pressing the cathode and anode on either side of the PHME at room temperature for $3 \mathrm{~min}$. It is noteworthy to mention here that when the binder layer consisting of PVA + glutaraldehyde comes in contact with $\mathrm{H}_{2} \mathrm{SO}_{4}$ soaked-PHME, it undergoes cross-linking and in this process binds the PHME with catalyst layer. A schematic diagram of the PHME-based MEA employed in this study is shown in figure 1.

PHME and NME-based MEAs were employed to assemble various liquid-feed DBFCs. The electrodes were contacted on their rear with fluid flow field plates machined from high-density graphite blocks in which channels connecting the main tank with the MEA were provided to achieve minimum masspolarization in the DBFCs. The ridges between the channels in the high-density graphite blocks on both sides of the MEA make electrical contact with the electrodes. A schematic diagram of the fluid flow field plate with an active area of $\sim 9 \mathrm{~cm}^{2}$ that is machined from high-density graphite blocks is shown in figure 2. The fluid flow field plate also functioned as a storage tank for fuel/oxidant. The graphite blocks were provided with electrical contacts that helped conduct the current to the external circuit. Through the channels, the tanks supply fuel and oxidant to the anode and cathode, respectively. The fuel comprised an optimized mixture of $1.7 \mathrm{M} \mathrm{NaBH}_{4}$ in 7.0 $\mathrm{M} \mathrm{NaOH}$ and the oxidant comprised an optimized mixture of $2.0 \mathrm{M} \mathrm{H}_{2} \mathrm{O}_{2}$ in $1.5 \mathrm{M} \mathrm{H}_{2} \mathrm{SO}_{4}{ }^{6}$ After installing the DBFCs in the test station, performance evaluation studies were initiated. Galvano- 
static-polarization data for various DBFCs were recorded by employing Bitrode (Model No. LCN 210-12; Bitrode Corporation Fenton, Missouri, USA).

\subsection{Cross-over studies on membrane electrolytes}

In order to evaluate the efficacies of PHME and NME as separators in DBFCs, ex-situ studies were carried out to determine the extents of cross-over of $\mathrm{H}_{2} \mathrm{O}_{2}, \mathrm{NaBH}_{4}, \mathrm{H}_{2} \mathrm{SO}_{4}$ and $\mathrm{NaOH}$ by employing a set-up as shown in figure 3 , where 'Tank $A$ ' contained $30 \mathrm{~mL}$ of an aqueous solution of the chemical species whose crossover is to be determined and 'Tank B' was filled with $30 \mathrm{~mL}$ of Milipore water. The two tanks were sandwiched by PHME or NME and held tightly in place with the help of a clamp (not shown in figure 3). The set-up was then kept at room temperature to allow the chemical species to crossover across the membrane. After elapse of the stipulated time, a small volume of the solution from 'Tank B' was pipetted out and analyzed for quantification of the analyte crossing over through the membrane. Determination of extent of $\mathrm{H}_{2} \mathrm{O}_{2}$ crossover was carried out by redox titration against standardized $\mathrm{KMnO}_{4}{ }^{39}$ Extent of $\mathrm{NaBH}_{4}$ crossover was determined spectrophotometrically ${ }^{39}$ by employing a UV-Visible spectrophotometer (UV-2450, Shimadzu). The extent of cross-over of $\mathrm{H}_{2} \mathrm{SO}_{4}$ and $\mathrm{NaOH}$

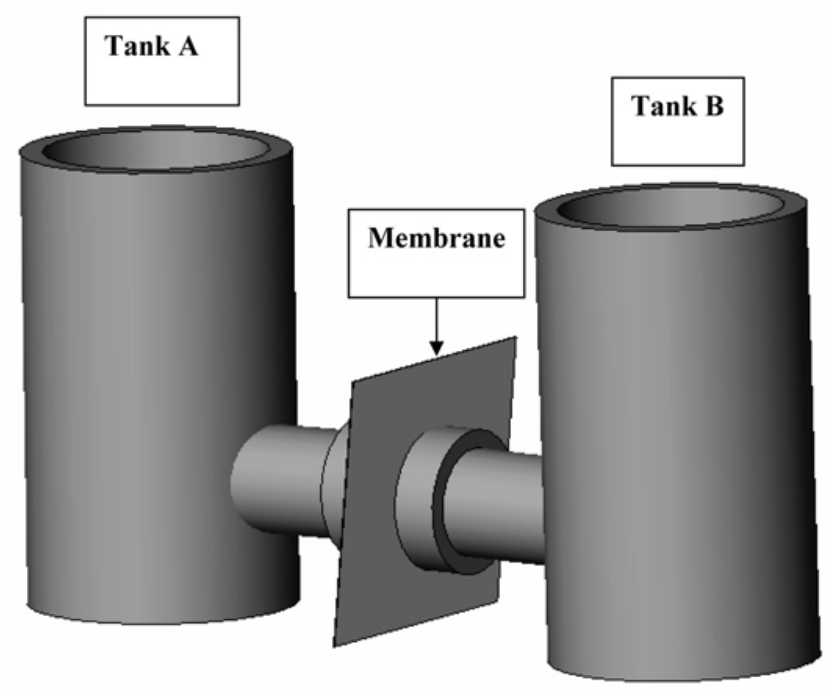

Figure 3. Schematic diagram of the set-up for ex-situ determination of extent of crossover of various chemical species employed in DBFCs through PHME and NME. 'Tank $A$ ' holds an aqueous solution of $\mathrm{H}_{2} \mathrm{O}_{2}, \mathrm{NaBH}_{4}$, $\mathrm{H}_{2} \mathrm{SO}_{4}$ or $\mathrm{NaOH}$ and 'Tank B' holds an equal volume of Millipore water. was determined by titrating against $\mathrm{Na}_{2} \mathrm{CO}_{3}$ and potassium phthalate, respectively.

\subsection{Utilization efficiency studies on fuel and oxidant}

Utilization efficiencies ${ }^{5}$ of $\mathrm{NaBH}_{4}$ and $\mathrm{H}_{2} \mathrm{O}_{2}$ in the DBFCs were determined from chronopotentiometric data recorded galvanostatically by employing an Autolab Electrochemical System (Eco Chemie, The Netherlands).

In a typical experiment, a $7 \mathrm{~mL}$ charge of fuel comprising $1.7 \mathrm{M} \mathrm{NaBH}_{4}$ in $7 \mathrm{M}$ aqueous $\mathrm{NaOH}$ was injected into the anode chamber and a $7 \mathrm{~mL}$ charge of oxidant comprising $2 \mathrm{M} \mathrm{H}_{2} \mathrm{O}_{2}$ in $1.5 \mathrm{M}$ aqueous $\mathrm{H}_{2} \mathrm{SO}_{4}$ was injected into the cathode chamber of the DBFC. The DBFC was then subjected to galvanostatic chronopotentiometric study at a load current density of $23 \mathrm{~mA} \mathrm{~cm}{ }^{-2}$. The fuel utilization efficiency of the DBFC was evaluated from the data collected by monitoring the anode potential until an abrupt change occurred in the anode polarization curve. In a similar fashion, the oxidant utilization efficiency was obtained by recording the cathode potential data until the inflection point.

\subsection{Cell performance durability studies on borohydride fuel cells}

Cell performance durability studies on DBFCs employing PHME and NME were carried out by recording their cell potentials as a function of time under a constant load current density of $10 \mathrm{~mA} \mathrm{~cm}$. In a typical experiment, the anode was supplied with a continuous flow of alkaline $\mathrm{NaBH}_{4}$ in a gravitydriven process and the cathode was supplied with a continuous charge of acidified $\mathrm{H}_{2} \mathrm{O}_{2}$ also in a gravity-driven arrangement for a continuous period of $100 \mathrm{~h}$. Outlets were provided to allow the used fuel and oxidant to pass out of the anode and cathode compartments, respectively.

\section{Results and discussion}

The PHMEs employed in this study are $\sim 210 \mu \mathrm{m}$ thick, transparent, colorless, and mechanically as well as chemically stable. ${ }^{31}$ The membrane casting procedure is designed so as to obtain a membrane of thickness close to that of Nafion-117. The use of a thinner membrane results in a lower open circuit voltage of the cell due to the increased cross-over of 
Table 1. Data pertaining to the crossover studies on DBFCs with PVA hydrogel and Nafion ${ }^{\circledR}-117$ membrane electrolytes.

\begin{tabular}{|c|c|c|c|c|c|c|c|c|c|}
\hline \multirow[b]{3}{*}{ Analyte } & \multirow[b]{3}{*}{ Parameter } & \multicolumn{4}{|c|}{$\begin{array}{l}\text { PVA hydrogel membrane } \\
\text { electrolyte }\end{array}$} & \multicolumn{4}{|c|}{$\begin{array}{c}\text { Nafion }^{\circledR}-117 \text { membrane } \\
\text { electrolyte }\end{array}$} \\
\hline & & \multicolumn{4}{|c|}{ Time (h) } & \multicolumn{4}{|c|}{ Time (h) } \\
\hline & & 1 & 2 & 3 & 24 & 1 & 2 & 3 & 24 \\
\hline \multirow[t]{2}{*}{$\mathrm{H}_{2} \mathrm{O}_{2}$} & Percentage crossed (\%) & 1.8 & 3.9 & $5 \cdot 4$ & $27 \cdot 3$ & 0.5 & $1 \cdot 0$ & $1 \cdot 4$ & 8.7 \\
\hline & Crossover rate $\left(\mathrm{m} \mathrm{mol} \mathrm{cm} \mathrm{cm}^{-2} \mathrm{~h}^{-1}\right)$ & $1 \cdot 5$ & $1 \cdot 7$ & $1 \cdot 5$ & $1 \cdot 0$ & $0 \cdot 4$ & $0 \cdot 4$ & $0 \cdot 4$ & $0 \cdot 3$ \\
\hline \multirow[t]{2}{*}{$\mathrm{NaBH}_{4}$} & Percentage crossed (\%) & - & - & - & 0.068 & - & - & - & $0 \cdot 142$ \\
\hline & Crossover rate $\left(\mathrm{m} \mathrm{mol} \mathrm{cm}-2 \mathrm{~h}^{-1}\right)$ & - & - & - & 0.0002 & - & - & - & 0.0004 \\
\hline \multirow{2}{*}{$\mathrm{H}_{2} \mathrm{SO}_{4}$} & Percentage crossed (\%) & $0 \cdot 7$ & $1 \cdot 4$ & $2 \cdot 4$ & $20 \cdot 5$ & $0 \cdot 2$ & $0 \cdot 5$ & $0 \cdot 5$ & $3 \cdot 4$ \\
\hline & Crossover rate $\left(\mathrm{m} \mathrm{mol} \mathrm{cm} \mathrm{ch}^{-2} \mathrm{~h}^{-1}\right)$ & $0 \cdot 6$ & $0 \cdot 6$ & $0 \cdot 6$ & $0 \cdot 7$ & $0 \cdot 1$ & $0 \cdot 2$ & $0 \cdot 1$ & $0 \cdot 1$ \\
\hline \multirow[t]{2}{*}{$\mathrm{NaOH}$} & Percentage crossed (\%) & $0 \cdot 6$ & $1 \cdot 1$ & 1.7 & $18 \cdot 3$ & $1 \cdot 1$ & $2 \cdot 3$ & $3 \cdot 4$ & $14 \cdot 7$ \\
\hline & Crossover rate $\left(\mathrm{m} \mathrm{mol} \mathrm{cm} \mathrm{cm}^{-2} \mathrm{~h}^{-1}\right)$ & 1.5 & 1.5 & 1.5 & 1.6 & $3 \cdot 1$ & $3 \cdot 1$ & $3 \cdot 1$ & $1 \cdot 2$ \\
\hline
\end{tabular}

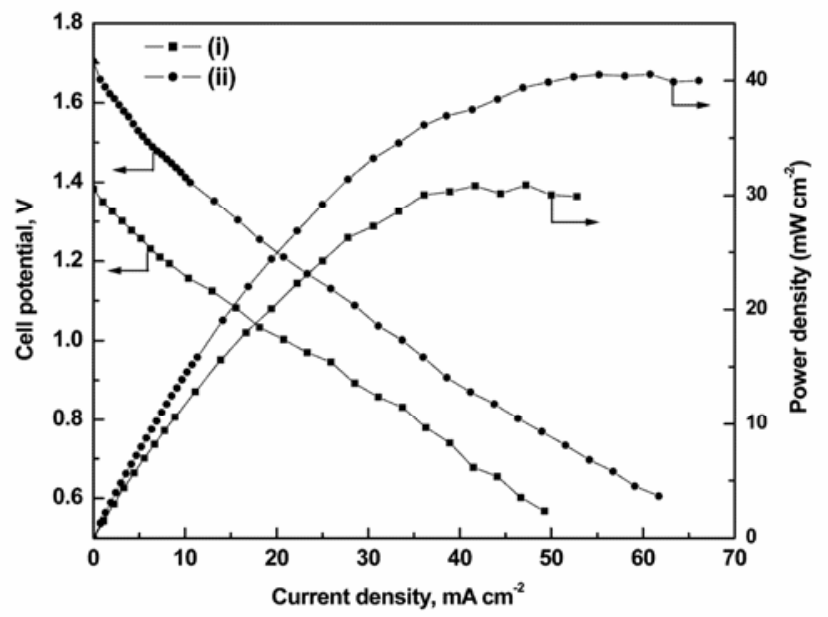

Figure 4. Cell performance data for DBFCs with (i) polyvinyl alcohol hydrogel membrane, and (ii) $\mathrm{Nafion}^{\circledR}$ 117 membrane electrolytes.

$\mathrm{BH}_{4}^{-}$ions from anode to cathode across the membrane. ${ }^{40}$ The mid-point ASTM glass transition temperature for the PHME obtained from time modulated differential scanning calorimetry using TOPEM software is found to be $381.3 \mathrm{~K}^{41}$ The ionic conductivity of as-prepared PHME is due to $\mathrm{H}_{2} \mathrm{SO}_{4}$ that is used to catalyze the cross-linking between PVA and glutaraldehyde. The schematic diagram of the PHME-based MEA employed in this study is shown in figure 1. Figure 1(a) shows the threedimensional side view and figure 1(b) shows the two-dimensional side view. As shown in figure 1(b), the components of the MEA are gold-plated SS mesh on anode side onto which the catalyst is coated (i), anode catalyst layer (ii), PVA + glutaraldehyde binder layer on anode side (iii), PHME (iv), PVA + glutaraldehyde binder layer on cathode side (v), gold-coated SS mesh used as cathode (vi).

The performance data for DBFCs with optimized PHME and NME are presented as graphs (i) and (ii) respectively in figure 4 . The open circuit potentials of DBFCs with PHME and NME are $\sim 1.4$ and $\sim 1.7 \mathrm{~V}$, respectively. The cell potentials and power densities of the PHME-based DBFC are lower than those of the NME-based DBFC. The peak power densities for the PHME and NME-based DBFCs are found to be $\sim 30$ and $\sim 40 \mathrm{~mW} \mathrm{~cm}{ }^{-2}$, respectively at ambient temperature. The load-current densities corresponding to peak power densities for the DBFCs with PHME and NME are $\sim 45$ and $\sim 60 \mathrm{~mA} \mathrm{~cm}^{-2}$, respectively. The nominally better cell performance of the NME-based DBFC could be due to the higher ionic conductivity of NME $\left(10^{-1} \mathrm{~S} \mathrm{~cm}^{-1}\right)$ that, unlike PHME $\left(10^{-2} \mathrm{~S} \mathrm{~cm}^{-1}\right)$, is an ionomer with pendant $-\mathrm{SO}_{3} \mathrm{H}$ side groups.

Data pertaining to the crossover of various chemical species involved in the two membrane-based DBFCs are summarized in table 1. The rate of $\mathrm{H}_{2} \mathrm{O}_{2}$ crossing over across PHME is found to be higher than that through NME. The mobility of $\mathrm{H}_{2} \mathrm{O}_{2}$ across the two membranes could be influenced by the physical characteristics of the two membranes such as thickness and density. The thicknesses of the two membranes being almost identical, the densities of the two membranes could be the determining factor. 
The density of the in-house prepared PHME and commercially prepared NME employed in this study have been determined to be 1.2 and $2.2 \mathrm{~g} \mathrm{~cm}^{-3}$, respectively. The relatively low density of PHME could be responsible for the higher cross over rate of $\mathrm{H}_{2} \mathrm{O}_{2}$.

The percentage of $\mathrm{NaBH}_{4}$ crossover across the two membranes is very small. Owing to this reason, the data for $\mathrm{NaBH}_{4}$ crossover after a period of $24 \mathrm{~h}$ only is reported here. The rate of $\mathrm{NaBH}_{4}$ crossover has been found to be nominally less across the PHME as compared to that across the NME. The crossover rate of $\mathrm{H}_{2} \mathrm{SO}_{4}$ across $\mathrm{PHME}$ is almost five times of that across NME. The higher rate of crossover of $\mathrm{H}_{2} \mathrm{SO}_{4}$ across PHME can be explained by considering the structural features of the two membranes and the mode of transportation of $\mathrm{H}_{2} \mathrm{SO}_{4}$ in aqueous medium. PHME is a nonionic membrane whereas NME is an ionomeric membrane with negatively charged $-\mathrm{SO}_{3}^{-}$groups attached to the Nafion ${ }^{\circledR}$ backbone. When $\mathrm{H}_{2} \mathrm{SO}_{4}$ is mixed with an aqueous medium like PHME, the protons get bonded to the network of $\mathrm{H}$-bonded water molecules through $\mathrm{H}$-bonding whereas the sulphate ion is surrounded by shells polar water molecules. The H-bonded protons transport by the Grötthus-type mechanism whereas the $\mathrm{HSO}_{4}^{-}$ions transport by free diffusion. Mobility of proton in aqueous medium is the highest among all the ions. ${ }^{31,42}$ So, the ion determining the rate of transportation of $\mathrm{H}_{2} \mathrm{SO}_{4}$ across the two membranes is $\mathrm{SO}_{4}^{2-}$. Now, $\mathrm{SO}_{4}^{2-}$ will experience a repulsive force while transporting through NME because of the negatively charged backbone of Nafion ${ }^{\circledR}$ ionomer. This explains the low mobility of $\mathrm{H}_{2} \mathrm{SO}_{4}$ across NME as compared to PHME. The rate of $\mathrm{NaOH}$ crossover through the PHME is almost half of that through the NME. This can be explained in a similar manner as that of $\mathrm{H}_{2} \mathrm{SO}_{4}$. Similar to $\mathrm{H}^{+}$ion, the $\mathrm{OH}^{-}$ ion in aqueous medium bonds to the matrix of $\mathrm{H}$-bonded water molecules and may predominantly transport by the Grötthus-type mechanism. The unique mode of transportation of $\mathrm{OH}^{-}$explains its high mobility in aqueous medium, next only to $\mathrm{H}^{+}$ ion mobility. ${ }^{42}$ So, the mobility of $\mathrm{NaOH}$ in aqueous medium-based membrane electrolytes will predominantly be dependent on the mobility of $\mathrm{Na}^{+}$that takes place by free diffusion. The electrostatic attraction between $\mathrm{Na}^{+}$ion and $-\mathrm{SO}_{3}^{-}$ions present in the Nafion ${ }^{\circledR}$ backbone facilitates the transportation of $\mathrm{Na}^{+}$across the NME. In contrast, the polymeric network in PHME being electrically neutral offers no such assistance in the transportation of $\mathrm{NaOH}$. This explains the higher crossover rate of $\mathrm{NaOH}$ in NME as compared to that in PHME. The mobility of various ions in Nafion ${ }^{\circledR}-117$ membrane reported in the literature ${ }^{43}$ supports this explanation.

The data pertaining to utilization efficiencies ${ }^{22}$ of $\mathrm{NaBH}_{4}$ and $\mathrm{H}_{2} \mathrm{O}_{2}$ for the PHME and NME-based DBFCs are shown in figure 5. Cell potential data for PHME and NME-based DBFCs are shown as graphs (i) and (ii), respectively. Cathode potential data for PHME and NME-based DBFCs are shown as graphs (iii) and (iv), respectively. Anode potential data for PHME and NME-based DBFCs are shown as graphs (v) and (vi), respectively. The utilization efficiencies of $\mathrm{NaBH}_{4}$ and $\mathrm{H}_{2} \mathrm{O}_{2}$ are found to be $\sim 24 \%$ and $\sim 59 \%$, respectively for the PHME-based DBFC. For NME-based DBFC, the utilization efficiencies of $\mathrm{NaBH}_{4}$ and $\mathrm{H}_{2} \mathrm{O}_{2}$ are found to be $\sim 18 \%$ and $\sim 62 \%$, respectively. As documented in table 1, although the crossover rate of $\mathrm{NaBH}_{4}$ across both the membranes is very low, its utilization efficiency in the DBFCs is also low. The loss of $\mathrm{NaBH}_{4}$ in the DBFCs could be mainly due to hydrolysis reaction. ${ }^{17}$ The fact that the utilization efficiencies of fuel and oxidant in the PHME-based DBFC are comparable to those in the NME-based DBFC shows that the PHME can be a viable electrolyte for use in DBFCs.

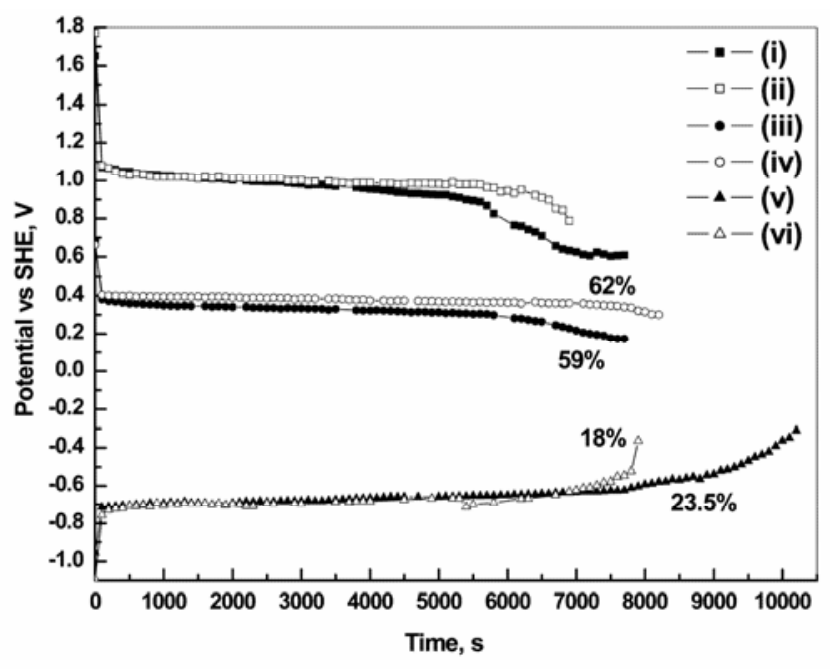

Figure 5. Chronopotentiometric data for determination of utilization efficiencies of $\mathrm{NaBH}_{4}$ and $\mathrm{H}_{2} \mathrm{O}_{2}$ in DBFCs: (i) cell potential data for PHME-based DBFC, (ii) cell potential data for NME-based DBFC, (iii) cathode potential data for PHME-based DBFC, (iv) cathode potential data for NME-based DBFC, (v) anode potential data for PHME-based DBFC, (vi) anode potential data for NMEbased DBFC. 


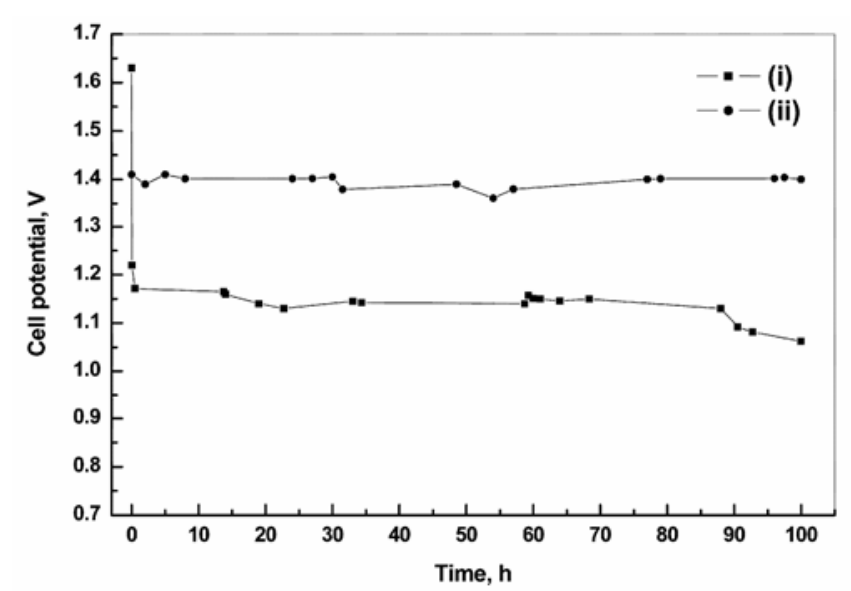

Figure 6. Data pertaining to cell performance durability tests on DBFCs with (i) polyvinyl alcohol hydrogel membrane, and (ii) Nafion ${ }^{\circledR}-117$ membrane electrolytes.

The data pertaining to the cell performance durability studies on the PHME and NME-based DBFCs are shown as graphs (i) and (ii), respectively in figure 6. For the PHME-based DBFC, a sharp fall in cell potential from $\sim 1.6$ to $\sim 1.2 \mathrm{~V}$ is observed when loaded with a small initial current. On continuation of current loading for $\sim 100 \mathrm{~h}$, there was little decrease in the cell potential. In the case of NMEbased DBFC, no initial sharp fall in cell potential is observed. The cell potential for the NME-based DBFC is found to be higher than that for the PHMEbased DBFC during the entire period of the durability test.

\section{Conclusions}

The study demonstrates that it is possible to assemble and operate a DBFC with PVA hydrogel membrane as electrolyte, alkaline $\mathrm{NaBH}_{4}$ as fuel and acidified $\mathrm{H}_{2} \mathrm{O}_{2}$ as oxidant. A maximum power density of $\sim 30 \mathrm{~mW} \mathrm{~cm}^{-2}$ is observed for the PHMEbased DBFC in contrast to $\sim 40 \mathrm{~mW} \mathrm{~cm}^{-2}$ for the NME-based DBFC at ambient temperature. The rate of $\mathrm{H}_{2} \mathrm{O}_{2}$ crossover across PHME is found to be almost three times that through NME. The percentage of $\mathrm{NaBH}_{4}$ crossover across the two membrane electrolytes is very small. The crossover rates of $\mathrm{NaBH}_{4}$ across PHME and NME has been found to be $1.8 \times 10^{-3}$ and $3.8 \times 10^{-3} \mathrm{~m} \mathrm{~mol} \mathrm{~cm}^{-2} \mathrm{~h}^{-1}$, respectively. The crossover rate of $\mathrm{H}_{2} \mathrm{SO}_{4}$ across PHME is almost five times that across NME. The rate of $\mathrm{NaOH}$ crossing over through the PHME is almost half of that through the NME. The utilization efficiencies of $\mathrm{NaBH}_{4}$ and $\mathrm{H}_{2} \mathrm{O}_{2}$ are found to be $\sim 24 \%$ and $\sim 59 \%$, respectively for the PHME-based DBFC. For NME-based DBFC, the utilization efficiencies of $\mathrm{NaBH}_{4}$ and $\mathrm{H}_{2} \mathrm{O}_{2}$ are $\sim 18 \%$ and $\sim 62 \%$ respectively. The PHME and NME-based DBFCs show cell potentials of $\sim 1.2$ and $\sim 1.4 \mathrm{~V}$ respectively at a load current density of $10 \mathrm{~mA} \mathrm{~cm}^{-2}$ for $\sim 100 \mathrm{~h}$ at ambient temperature. The performance of the PHME-based DBFC compares well with the NMEbased DBFC.

\section{Acknowledgement}

The financial support from US Army Communication and Electronics Research Development and Engineering Center (CERDEC) is gratefully acknowledged.

\section{References}

1. Larminie J and Dicks A 2000 Fuel cell systems explained (New York: Wiley)

2. Isono T, Suzuki S, Kaneko M, Akiyama Y, Miyake Y and Yonezu I 2000 J. Power Sources 86269

3. Igarashi H, Fujino T and Watanabe M 1995 J. Electroanal. Chem. 391119

4. Prakash G K S, Smart M C, Wang Q.-J, Atti A, Pleynet V, Yang B, McGrath K, Olah G A, Narayanan S R, Chun W, Valdez T and Surampudi S 2004 J. Fluorine Chem. 1251217

5. Aricò A S, Srinivasan S and Antonucci V 2001 Fuel Cells 11

6. Shukla A K, Jackson C L, Scott K and Raman R K 2002 Electrochim. Acta 473401

7. Shukla A K, Jackson C L and Scott K 2003 Bull. Mater. Sci. 26207

8. Shukla A K, Raman R K, Choudhury N A, Priolkar K $\mathrm{R}$, Sarode P R, Emura S and Kumashiro R $2004 \mathrm{~J}$. Electroanal. Chem. $\mathbf{5 6 3} 181$

9. Indig M E and Snyder R N 1962 J. Electrochem. Soc. 1091104

10. Jung M and Kroeger H H 1970 US Patent 3,511,710

11. Lee J.-Y 1997 US Patent 5,599,640

12. Amendola S C 1998 US Patent 5,804,329

13. Amendola S C, Onnerud P, Kelly M, Petillo P, SharpGoldman S and Binder M 1999 J. Power Sources 84 130

14. Suda S 2002 US Patent $6,358,488$

15. Li Z P, Liu B H, Arai K and Suda S 2003 J. Electrochem Soc. 150 A868.

16. Li Z P, Liu B H, Arai K, Asaba K and Suda S $2004 J$. Power Sources 12628

17. Fakioğlu E, Yürüm Y and Veziroğlu T N 2004 Int. J. Hydrogen Energy 291371

18. Suda S 2003 In Handbook of fuel cells: Fundamentals, technology and applications (eds) W Vielstich, H A Gasteiger and A Lamm Fuel Cell Technology and Applications (Wiley) vol 3, p 115-120 
19. Leon C P D, Walsh F C, Pletcher D, Browning D J and Lakeman J B 2006 J. Power Sources 155172

20. Choudhury N A, Raman R K, Sampath S and Shukla A K 2005 J. Power Sources 1431

21. Raman R K, Choudhury N A and Shukla A K 2004 Electrochem. and Solid-State Lett. 7 A488

22. Raman R K and Shukla A K 2007 Fuel Cells 7225

23. Raman R K, Prashant S K and Shukla A K 2006 J. Power Sources 1621073

24. Lewandowski A, Skorapaka K and Malinska J 2000 Solid State Ionics 133265

25. Vargas R A, Zapata V H, Matallana E and Vargas M A 2001 Electrochim. Acta 461699

26. Rhim J W, Hwang H S, Kim D S, Park H B, Lee C H, Lee Y M, Moon G Y and Nam S Y 2005 Macromol. Res. 13135

27. Kang M S, Kim J H, Won J, Moon S H and Kang Y S 2005 J. Membr. Sci. 247127

28. Araujo A M, Neves M T, Azevedo W M, Oliveira G G, Ferreira D L, Coelho R A L, Figueiredo E A P and Carvalho L B 1997 Biotechnology Tech. 1167

29. Qiao J, Hamaya T and Okada T 2005 J. Mater. Chem. 154414

30. Kim S Y, Shin H S, Lee Y M and Jeong C N 1999 J. Appl. Polym. Sci. 731675

31. Choudhury N A, Shukla A K, Sampath S and Pitchumani S 2006 J. Electrochem. Soc. 153 A614
32. Dasenbrock C O, Ridgway T H, Seliskar C J and Heineman W R 1998 Electrochim. Acta 433497

33. Kumar V G, Shaju K M, Munichandraiah N and Shukla A K 1998 J. Power Sources 76106

34. Shukla A K, Venugopalan S and Hariprakash B 2001 J. Power Sources 100125

35. Tliha M, Mathlouthi H, Lamloumi J and PercheronGuegan A 2007 J. Alloys Compounds 436221

36. Srivastava S and Srivastava O N 1998 J. Alloys Compounds 267240

37. Li R, Wu J-M and Wang X-I 2000 J. Alloys Compounds $\mathbf{3 1 1} 40$

38. Wang L, Ma C, Sun Y and Suda S 2005 J. Power Sources 391318

39. Jeffery G H, Bassett J, Mendham J and Denney R C 1989 Vogel's textbook of quantitative chemical analysis (Fifth edition)

40. Liu B H, Li Z P, Zhu J K and Suda S 2008 J. Power Sources 183151

41. Sahu A K, Selvarani G, Pitchumani S, Sridhar P, Shukla A K, Narayanan N, Banerjee A and Chandrakumar N 2008 J. Electrochem Soc. 155 B686S

42. Puri B R, Sharma L R and Pathania M S 1996 Principles of physical chemistry (Shoban Lal Nagin Chand and Co., Educational Publishers: India)

43. Stenina I A, Sistat Ph, Rebrov A I, Pourcelly G and Yaroslavtsev A B 2004, Desalination 17049 